\title{
Qualitative research: Exploring the multiple perspectives of osteopathy
}

\author{
Oliver P. Thomson, Nicola J. Petty, Charlotte M. Ramage, \\ Ann P. Moore
}

\begin{abstract}
This paper is offered as an introduction to qualitative research, with the hope that it informs and stimulates osteopaths and researchers who are unfamiliar with this area of research. This paper discusses the potential contribution of qualitative research in exploring the complex and multiple aspects of osteopathy and how the fi of qualitative studies may contribute to the knowledge base of osteopathy. A defi ion of qualitative research is provided, and a number of different methodologies are discussed. Finally it suggests examples of how the findings of qualitative research could potentially help inform osteopathic practice.
\end{abstract}

\section{KEYWORDS}

Osteopathy; Osteopathic medicine; Qualitative; Research; Knowledge; Evidence-based medicine

\section{Introduction}

The last 20 years has seen a dramatic rise in the amount of qualitative health research undertaken, and qualitative research is now regularly published in a range of medical journals (for example, The Lancet, BMJ, and Social Science and Medicine) and there are numerous books, journals and conferences dedicated to qualitative research methods. ${ }^{1}$
The contribution that qualitative research makes to practice has been discussed in a variety of health professions literature, including Medicine, ${ }^{2 \mathrm{e} 6}$ Dentistry, ${ }^{7 \mathrm{e} 9}$ Nursing, ${ }^{10 \mathrm{e} 12}$ Occupational Therapy, ${ }^{13 \mathrm{e} 15}$ and Physiotherapy. ${ }^{16 \mathrm{e} 24}$ While qualitative research has received some attention from osteopathic researchers, ${ }^{25 e 27}$ its potential contribution to the osteopathic body of knowledge is yet to be formally discussed. As well as exploring the practice of qualitative research, this paper considers the role that qualitative research could have in broadening our understanding of the multiple perspectives of osteopathy. 


\section{Qualitative research}

The choice of research methodology largely depends on the nature of the question asked. Questions such as "How many patients would consult their osteopath when they have an episode of acute neck pain?" or "What proportion of osteopaths take an evidence-based approach in their management of patients with low back pain?" would clearly be better answered through quantitative methods. However, questions such as "Why do patients feel the need to seek help from an osteopath during an episode of acute neck pain"? and "Why do some osteopaths take an evidencebased approach to their practice?" could only be effectively answered via qualitative inquiry, which would provide a contextualised and deep understanding of the phenomena experienced by the individual or group under study.

Qualitative research facilitates an understanding of social phenomena in the natural setting, often from the perspectives of the participants. ${ }^{20}$ As a process of research, qualitative methods have been developed to allow a systematic investigation of how individual participants 'make sense' of the world and how they interpret and experience events. ${ }^{28}$ The type of data collected, or even how it is collected is not the most fundamental difference between qualitative and quantitative research. Rather the major difference lies in the foundational assumptions, 'the givens' which determine the worldview of the holder, and forming the paradigm to which the research approach belongs. ${ }^{29}$ Quantitative research often takes a positivist view of knowledge, in that it assumes there is a knowable, single objective reality, which may be explored (tested) by experimental studies. ${ }^{20}$ Such studies (for example randomised controlled trials) are often heavily controlled, include a large number of subjects, with the aim to provide an explanation of the 'working components' of who we are and how we work. ${ }^{21}$ In practice, quantitative research aims to test experimental hypothesis from existing theories and involves collecting data on predetermined instruments, which are then quantified and statistically analysed. ${ }^{30}$ Quantitative research typically to identify the cause and effect of an intervention on the 'average' patient, within the inclusion criteria of the trial; the findings cannot be automatically applied to an individual patient in the clinic.

On the other hand qualitative research may take an interpretivist view of knowledge, seeking an understanding of a particular phenomenon, and

improve standards of healthcare in the UK by the promotion of lifelong learning for health professionals. The evidence based practice 'movement' has reached almost all corners of the world, ${ }^{39,40}$ and the EBP model is promoted as the optimal considers the context of the research study is essential to the interpretation of the data gathered. ${ }^{31}$ Rather than searching for law-like explanations, interpretivist research aims to provide an understanding of the studied phenomena. The interpretivist paradigm has been advocated as being well suited to the generation of knowledge in the social sciences, in both the philosophical stance it assumes and the methods utilised to collect and analyse data. ${ }^{32}$ The resulting understanding generated in the interpretive paradigm assumes "emergent, multiple realities; indeterminacy; facts and values as linked; truth as provisional; and social life as processual". ${ }^{33}$ In accordance with this, qualitative research looks for answers to questions that emphasise how social experience is created and given meaning. ${ }^{28}$

The view of the world that the researcher takes is intricately linked to the research methodology and research methods used to conduct the research. In the qualitative tradition, methodology may be defined as "the principles and ideas on which researchers base their procedures and strategies (methods)". ${ }^{34}$ On the other hand, research methods are the activities of research, such as the sampling of participants, data collection (for example interviews, focus groups or observation), data management and analysis. ${ }^{35} \mathrm{It}$ should be added that a single study may combine both qualitative and quantitative research methodologies, taking a 'mixed methods' approach to research. ${ }^{36}$ There are numerous ways of combining qualitative and quantitative research depending on the area of research or research question. Mixed methods research may be used in the following ways, for example; to help explain the findings generated by either one of the research methods; to triangulate the findings from both approaches so they may be mutually corroborated; or by 'discover and confirm', which may involve generating hypotheses via qualitative data and then employing quantitative research to test them. ${ }^{31}$

\section{Qualitative research and evidence informed osteopathy}

Since the 1980's there has been a growing movement away from clinical practice that is guided by belief, to one informed by, and incorporating, research evidence. While the philosophical foundations of evidence-based practice (EBP) date back to the mid 19 th century, ${ }^{37}$ a major driving force was the advent of the Department of Health Quality Agenda in 1998, ${ }^{38}$ which in part aimed to approach to practice in many healthcare professions, including Medicine ${ }^{41}$ and Physiotherapy. ${ }^{42 e 44}$ The osteopathic profession has not escaped the EBP debate, with many scholars and researchers in agreement that some form of EBP needs to be 
integrated into the osteopathic approach. ${ }^{45 e 49}$ It has been suggested that a preferred term is 'evidence-informed osteopathy' recognising and reinforcing the idea that evidence should never replace practice rather it should inform it. ${ }^{45,48,49}$ What 'counts', as evidence is fiercely debated, ${ }^{18,50,51}$ and findings from qualitative research currently resides in the 'lower levels of evidence' category, within the current model of EBP. ${ }^{41}$ An over emphasis on the value of findings from the 'higher levels of research' (according to the current EBP model), such as those from randomised controlled trials, fails to acknowledge the importance of human experience in clinical practice, which qualitative research lends itself to exploring. However, there is an increasing dissatisfaction with the EBP model as it stands across a number of different health professions including medicine. ${ }^{42,52 e 55}$

\section{Ensuring quality in qualitative research}

Just as in quantitative research, qualitative research needs to take measures to ensure its quality. However the unique perspective and methodological approaches that qualitative research adopts means that the 'rules of rigour' which are applied to quantitative studies, need adapting for qualitative methods. Complicating matters is the fact that researchers have yet to agree on a common criteria for judging the quality of qualitative research, mainly due to the different paradigms and philosophical stances which qualitative researchers may take. ${ }^{56}$ The application of the term 'rigour' in qualitative research is much debated. ${ }^{5659}$ Some argue that implementing strict criteria for rigour will stifle the creativity of qualitative research. ${ }^{58}$ Others accept that while there is tension between rigour and creativity, some kind of validity criteria and some methodological or technical procedures are essential to guard against the investigator's 'conjuring up' concepts and theories that do not authentically represent the phenomenon of concern. ${ }^{60} \mathrm{~A}$ lack of a unified consensus on methodological approach, and an inability to fully generalise the findings of qualitative studies, means that qualitative research is often undervalued and relegated to the status of a 'soft science'. However, when considering that a softer, flexible approach is necessary when attempting to understand social processes, and human experiences, the term 'soft science' may be regarded as appropriate. Moreover, as the use of qualitative research continues to evolve and proliferate in the healthcare arena and with new emerging methods requiring refinement, a fluid and flexible approach is suggested for the evaluation of qualitative research. ${ }^{60}$

More suitable to qualitative research is the concept of trustworthiness, which aims to move the responsibility for judging the quality of the research from the producer to the reader. ${ }^{56}$ Trustworthiness encompasses 'credibility', 'transferability', 'dependability' and 'confirmability' which are used to replace the terms of internal and external validity, reliability and objectivity ${ }^{61}$ used in quantitative research. Table 1 compares the criteria of rigour in quantitative and qualitative research. Qualitative researchers have a number of strategies to ensure and assess the trustworthiness of their research, in line with the methodological approach that they take. For example, the criterion of credibility aims to provide confidence that the research has obtained an accurate interpretation of the meaning of the data which reflect the experience of participants. ${ }^{60}$ Credibility of a study may be enhanced by the process of 'member checking', which involves participants confirming that the data collected (for example following an interview) represents an accurate account of what was said, and participants are then sometimes asked to make further comments if necessary. ${ }^{31}$

Similar to the external validity criteria used in quantitative research, transferability is the extent to which the ideas generated may be applied to other populations or situations, and may be considered the generalisability of the findings. ${ }^{31}$ For example, during research using interview methods to collect data, transferability may be enhanced by obtaining what is known as "thick descriptions", i.e. those which are "deep, dense, detailed accounts"62, p. ${ }^{83}$ ). In addition, by writing in thick descriptions during the analysis, researchers aim to contextualise the detailed accounts of the interviewee's experiences. Providing such contextualised and rich descriptions allows the reader to judge whether theoretical concepts of the research findings might be transferable to other people in other settings, whilst also evaluating the quality of the research. For example, 'thick descriptions' would allow the 
Table 1 Comparison of criteria for quality in quantitative and qualitative research.

\begin{tabular}{|c|c|c|c|}
\hline \multicolumn{2}{|c|}{ Quantitative Rigour ${ }^{64}$} & \multicolumn{2}{|l|}{ Qualitative Trustworthiness ${ }^{61}$} \\
\hline $\begin{array}{l}\text { Internal } \\
\text { Validity }\end{array}$ & $\begin{array}{l}\text { Causal relationship between two } \\
\text { variables and whether the study } \\
\text { measured that which it was } \\
\text { intended to measure. }\end{array}$ & $\begin{array}{l}\text { The research has obtained an } \\
\text { accurate interpretation of the } \\
\text { meaning of the data which } \\
\text { reflects the experience of } \\
\text { participants. }\end{array}$ & Credibility \\
\hline $\begin{array}{l}\text { External } \\
\text { Validity }\end{array}$ & $\begin{array}{l}\text { Being able to generalize to } \\
\text { a Larger population associated } \\
\text { with one's research sample. }\end{array}$ & $\begin{array}{l}\text { The extent to which the ideas } \\
\text { generated may be applied to } \\
\text { other populations or situations. }\end{array}$ & Transferability \\
\hline Objectivity & $\begin{array}{l}\text { The absence of bias, by the } \\
\text { researcher maintaining } \\
\text { 'distance' between } \\
\text { researcher and research. }\end{array}$ & $\begin{array}{l}\text { The degree to which the researcher } \\
\text { can demonstrate that the findings } \\
\text { relate to the data. }\end{array}$ & Confirmability \\
\hline Reliability & $\begin{array}{l}\text { The extent to which results are } \\
\text { consistent over time and an } \\
\text { accurate representation of the } \\
\text { total population under study. }\end{array}$ & $\begin{array}{l}\text { Whether the findings of the study } \\
\text { offer a dependable and realistic } \\
\text { interpretation of the view held } \\
\text { by the participants. }\end{array}$ & Dependability \\
\hline
\end{tabular}

reader to judge the extent to which the findings of a qualitative study exploring the experiences of individuals with chronic low back pain in the U.K are transferable to individuals with chronic neck pain in Australia. Importantly, such studies facilitate further research, which when combined with other similar studies represents a form of triangulation, with each study building up the previous, to provide an in-depth understanding of the phenomenon. ${ }^{28}$ If the findings of multiple studies are consistent enough, they may be considered to be theoretically transferable, rather than statistically generalizable. ${ }^{63}$

Detailing the methods used by the researcher to collect and analyse data in all phases of the study, enables the reader to follow and verify the research process, serving as an 'audit trail'61, which aims to increase the dependability and confirmability of a qualitative study. The writing of memos, interview transcripts, interview notes, interview guides, regular logs into a research diary can all provide a 'decision trail', documenting each stage of the inquiry process. ${ }^{57}$

\section{How can qualitative research help inform osteopathic practice?}

It is recognised that part of the osteopathic approach to healthcare is to treat the patient with the disease and not treat just the disease or dysfunction in the biomedical sense. Such an acknowledgement means that it is necessary to obtain an understanding of the patients' experiences, and disability from their perspective, so that the patient and practitioner can decide upon the most appropriate line of treatment. Qualitative research methods could enable osteopathic researchers to explore patient's beliefs, attitudes and values, and how they make sense of their life, pain or illness. This understanding could help osteopaths care for their patients more effectively and enhance their clinical practice. In addition, the findings of qualitative studies could also form a 'contextual envelope' for the application of quantitative research evidence. With a detailed understanding of the unique perspective that each person has, quantitative research findings, such as the outcomes of randomised controlled trials, could be applied in a more meaningful and relevant way.

While research on the efficacy of therapeutic interventions using quantitative research is important, the findings they produce are traditionally devoid of the patient's voice, which conveys their unique experiences and perspective. Osteopathy is (or should be) much more than a technique driven profession, matching up manipulation or mobilisation technique based on the perceived and often unreliably palpated dysfunction within a passive patient. After examining a patient, findings are situated both temporally and socially, and the practitioner should endeavour to link the local and specific physical findings with the verbal information from the patient ${ }^{65}$ to help facilitate a patient-centred approach to practice. An examination orientated purely in the quantitative domain, for example such as manually quantifying joint range of motion, has significant limitations. The greatest weakness of this approach is its failure to acknowledge the values, 
expectations, and illness experience of the individual patient; the right treatment cannot be matched to the right patient. ${ }^{66}$

If we are to consider our traditional osteopathic approach to healthcare in the context of contemporary models of health and disability, ${ }^{67 e 69}$ then we need research that will help us understand our patients (and ourselves) so that the profession can deliver the highest standards of care. For example, the International Classification of Functioning, Disability and Health (ICF) ${ }^{69}$ which is based on the WHO framework of health and disability, recognises patients within a biopsychosocial model of healthcare and considers disability as more than a 'medical' or 'biological' dysfunction, and takes into account the social aspects of disability. Making use of qualitative research evidence, of which the findings are based on the patient experiences, would give an invaluable understanding of how biological, personal and social factors impact on a patient's illness or health experiences.

In adopting a patient-centred approach to practice, many other health professions have begun to use qualitative research to explore the more discrete areas of their practice. Table 2 below provides examples of published qualitative research studies by a range of health professions, using four different qualitative methodologies, from three different perspectives. These examples offer a tantalising view of research areas which await an osteopathic exploration, and provide an intriguing insight into how the knowledge generated from such studies would be valuable to the profession as a whole.

\section{The potential contributions of qualitative research to osteopathy}

There are many exciting avenues within osteopathy that qualitative research methodologies could help explore. For example, Grounded theory, which aims to explore social processes, ${ }^{103}$ could be used to provide an insight into how osteopaths make treatment and management decisions with their patients. It could help develop an understanding of the differences between osteopaths who have different backgrounds of training, models of practice and levels of experience. A grounded theory study could explore patterns in their clinical practice, and enable the construction

Table 2 Examples of published qualitative health research from three different perspectives.

\begin{tabular}{|c|c|c|c|}
\hline Methodology & Patients' Perspective & Clinicians' Perspective & Professional Perspective \\
\hline \multirow[t]{2}{*}{$\begin{array}{l}\text { Grounded } \\
\text { Theory }\end{array}$} & $\begin{array}{l}\text { Patients experience and } \\
\text { reporting of pain following } \\
\text { manual therapy treatment }\end{array}$ & $\begin{array}{l}\text { Nature and development } \\
\text { of clinical expertise of } \\
\text { physiotherapists }\end{array}$ & $\begin{array}{l}\text { Educational dimensions of } \\
\text { physiotherapy practice }^{82}\end{array}$ \\
\hline & $\begin{array}{l}\text { Exploring cancer patients } \\
\text { experience of suffering }\end{array}$ & $\begin{array}{l}\text { Clinical reasoning of } \\
\text { physiotherapists }^{79 e 81}\end{array}$ & $\begin{array}{l}\text { Barriers to implementing and } \\
\text { adopting evidence-based } \\
\text { medicine }^{83}\end{array}$ \\
\hline \multirow[t]{2}{*}{ Phenomenology } & $\begin{array}{l}\text { Exploring patients' attitudes } \\
\text { to chronic pain }{ }^{84}\end{array}$ & $\begin{array}{l}\text { Experiences of expert nurses } \\
\text { in caring for patients with } \\
\text { postoperative pain }{ }^{86}\end{array}$ & $\begin{array}{l}\text { Perceptions of } \\
\text { complementary therapies } \\
\text { among other health } \\
\text { professions }^{88}\end{array}$ \\
\hline & $\begin{array}{l}\text { The experience of healing in } \\
\text { post-surgery patients }{ }^{85}\end{array}$ & $\begin{array}{l}\text { The nature of clinical } \\
\text { competence of occupational } \\
\text { therapists }^{87}\end{array}$ & $\begin{array}{l}\text { Problem-based learning in } \\
\text { medical education }{ }^{89}\end{array}$ \\
\hline \multirow[t]{2}{*}{ Ethnography } & $\begin{array}{l}\text { Family consequences of } \\
\text { chronic back pain }{ }^{90}\end{array}$ & $\begin{array}{l}\text { The types of knowledge used } \\
\text { in nursing practice }\end{array}$ & $\begin{array}{l}\text { Exploration of the use of } \\
\text { evidence-based pain } \\
\text { management }^{94}\end{array}$ \\
\hline & $\begin{array}{l}\text { Patients experience of pain } \\
\text { and disability and the } \\
\text { process of rehabilitation }\end{array}$ & $\begin{array}{l}\text { A study of physiotherapists' } \\
\text { perceptions of their } \\
\text { interactions with patients on } \\
\text { a chronic pain unit }{ }^{93}\end{array}$ & $\begin{array}{l}\text { Nursing leadership: } \\
\text { influencing and shaping } \\
\text { health policy and nursing } \\
\text { practice }^{95}\end{array}$ \\
\hline \multirow[t]{2}{*}{$\begin{array}{l}\text { Discourse } \\
\text { Analysis }\end{array}$} & $\begin{array}{l}\text { The experience of falling } \\
\text { amongst older people }\end{array}$ & $\begin{array}{l}\text { Strategies used by } \\
\text { occupational therapists to } \\
\text { empower their patients }\end{array}$ & $\begin{array}{l}\text { The interaction between the } \\
\text { clinical educator and the } \\
\text { physiotherapy student during } \\
\text { clinical supervision }{ }^{101}\end{array}$ \\
\hline & $\begin{array}{l}\text { Interaction between } \\
\text { physiotherapists and } \\
\text { patients in Stroke } \\
\text { treatment }^{98}\end{array}$ & $\begin{array}{l}\text { A Discourse analysis of } \\
\text { nursing diagnosis }\end{array}$ & $\begin{array}{l}\text { The representation of } \\
\text { medical doctors in the } \\
\text { Australian press }\end{array}$ \\
\hline
\end{tabular}


of a theoretical model of osteopathic clinical reasoning. This would have implications both educationally and professionally. Methods of data collection might include observing practitioners in their day-to-day practice with patients, which may be video recorded and subsequently analysed.

A phenomenological qualitative approach which seeks to understand the nature or meaning of every-day lived experiences ${ }^{104}$ could be used to explore the meanings that both osteopath and patient experience during a period of treatment. In-depth interviewing may be the data collection method of choice in order to provide descriptions of the life-world of the interviewee with respect to interpreting the meaning of the described phenomenon. ${ }^{105}$ Understanding this experience through the eyes of person(s) experiencing it, could provide a rich insight into the osteopathpatient encounter, which would almost certainly lead to implications on how osteopaths deliver their treatment and examination procedures.

Ethnography which is related to culture, social organisation and local perspectives, is concerned with understanding how groups of people sharing similar experiences give meaning to everyday life experiences. ${ }^{106}$ A simple example might be to help answer the question, "what is life like for people with chronic low back pain". Methods of data collection may include observation of participants in their 'natural setting' such as at home or at work, which may be supplemented with focus groups, to provide a detailed picture of the experience of these individuals. Obtaining this sort of insight could provide the profession with an enhanced understanding of the value of osteopathy for this specific group and refine the type and timing of the osteopathic care provided.

Finally, there are qualitative methodologies which emphasise the importance of language and communication (such as talk and text), and how language is used to create and enact identities and activities. ${ }^{107,108}$ For example, Discourse analysis has been used to good effect in the field of psychology to explore issues concerned with health, illness and health interventions. Discourse analysts argue "language and words, as a system of signs, are in themselves essentially meaningless; it is through the shared, mutually agreed-on use of language that meaning is created". ${ }^{107}$ Such an approach could be used to explore the dialogue used during osteopathic treatment sessions, and how it shapes the patients' and osteopaths' roles and identities in the therapeutic relationship. This would provide an insight to the 'osteopathic language' we use with our patients, and may challenge our assumptions of what we consider to be the most effective way of communicating with our patients. This sort of information would be valuable to osteopathic educators and most importantly our patients.

\section{Summary}

As members of the osteopathic profession, we each have our own unique expectations, beliefs and values which affect our practice, clinical behaviour and the way that we treat and manage our patients. Moreover, our patients have their own unique perspectives on how they view their health and disability, and their perceptions and expectations of consulting an osteopath. These areas of practice demand a different approach as 'numbers' are incapable of capturing the detail, depth and individuality of the social phenomena.

There is rising interest in qualitative research within the healthcare arena, and many other healthcare professionals have acknowledged the value of qualitative research to their clinical and professional practice. A wide range of research methodologies, both quantitative and qualitative are necessary to help us understand the multidimensional and complex nature of osteopathy. Qualitative research offers a unique approach to exploring the different perspectives of osteopathy, thereby opening many avenues of research within osteopathic practice. Qualitative research would provide an additional and much needed dimension to evidence-informed osteopathy, with the findings which are contextual and situational, allowing them to inform the multiple perspectives of osteopathic practice.

\section{References}

1. Sandelowski M. Using qualitative research. Qual Health Res 2004;14:1366e86.

2. Green J, Britten N. Qualitative research and evidence based medicine. Br Med J 1998;316:1230.

3. Barbour RS. The role of qualitative research in broadening the 'evidence base' for clinical practice. J Eval Clin Pract 2000;6:155e63. 
4. Greenhalgh T, Taylor R. How to read a paper: papers that go beyond numbers (qualitative research). Br Med J 1997; 315:740.

5. Popay J, Williams G. Qualitative research and evidencebased healthcare. J Roy Soc Med 1998;91:32.

6. Malterud K. The art and science of clinical knowledge: evidence beyond measures and numbers. Lancet 2001; 358:397e400.

7. Stewart K, Gill P, Chadwick B, Treasure E. Qualitative research in dentistry. Br Dent J 2008;204:235e9.

8. Meadows LM, Verdi AJ, Crabtree BF. Keeping up appearances: using qualitative research to enhance knowledge of dental practice. J Dent Educ 2003;67:981.

9. Masood M, Masood Y, Newton T. Methods of qualitative research in dentistry: a review. Dent Update 2010;37:326.

10. Holloway I, Wheeler S. Qualitative research in nursing and healthcare. Wiley-Blackwell; 2009.

11. Munhall PL. Nursing research: a qualitative perspective. Jones \& Bartlett Learning; 2001.

12. Newman M, Thompson C, Roberts AP. Helping practitioners understand the contribution of qualitative research to evidence-based practice. Evid Based Nurs 2006;9:4e7.

13. Hasselkus BR. Beyond ethnography: expanding our understanding and criteria for qualitative research. Occup Ther $J$ Res 1995;15:75e84.

14. Hammell KW. Using qualitative research to inform the client-centred evidence-based practice of occupational therapy. Br J Occup Ther 2001;64:228e34.

15. Finlay L. Multiple voices, multiple paths: choosing between qualitative traditions. Br J Occup Ther 2000;63:580e2.

16. Grant A. The use of qualitative research methodologies within musculoskeletal physiotherapy practice. Man Ther 2005; 10:1e3.

17. Jensen GM. Qualitative methods in physical therapy research: a form of disciplined inquiry. Phys Ther 1989;69: 492e500.

18. Gibson BE, Martin DK. Qualitative research and evidencebased physiotherapy practice. Physiotherapy 2003;89: $350 \mathrm{e} 8$.

19. Ritchie JE. Using qualitative research to enhance the evidence-based practice of health care providers. Aust J. Physiother 1999;45:251e8.

20. Guba E, Lincoln Y. Competing paradigms in qualitative research. In: Denzin NK, Lincoln YS, editors. Handbook of qualitative research. Thousand Oaks, Calif.; London: Sage Publications; 1994. p. $105 \mathrm{e} 17$.

21. Nicholls D. Qualitative research: part one e philosophies. Int J Ther Rehabil 2009;16:526e33.

22. Nicholls D. Qualitative research: part two e methodologies. Int J Ther Rehabil 2009;16:586e92.

23. Nicholls D. Qualitative research: part three e methods. Int $J$ Ther Rehabil 2009;16:638e47.

24. Johnson R, Waterfield J. Making words count: the value of qualitative research. Physiother Res Int 2004;9:121e31.

25. Zamani J, Vogel S, Moore A, Lucas K. Analysis of exercise content in undergraduate osteopathic education a content analysis of UK curricula. Int J Osteopath Med 2007;10:97e103.

26. Grundy M, Vogel S. Attitudes towards prescribing rights: a qualitative focus group study with UK osteopaths. Int J Osteopath Med 2005;8:12e21.

27. Carnes $D$, Underwood $M$. The importance of monitoring patient's ability to achieve functional tasks in those with musculoskeletal pain. Int J Osteopath Med 2008;11: $26 e 32$.

28. Denzin NK, Lincoln YS. Introduction: the discipline and practice of qualitative research. In: Denzin NK, Lincoln YS, editors. Strategies of qualitative inquiry. 3rd ed. London: SAGE; 2008. p. 1 e43.

29. Willis J. Foundations of qualitative research: interpretive and critical approaches. London: SAGE; 2007.

30. Creswell JW. Research design: qualitative, quantitative, and mixed methods approaches. 2nd ed. Thousand Oaks, Calif., London: Sage; 2003.

31. Bryman A. Social research methods. 3rd ed. Oxford: Oxford University Press; 2008.

32. Higgs J, Titchen A. Knowledge and reasoning. In: Higgs J, Jones $M$, editors. Clinical reasoning in the health professions. 2nd ed., vol. xiv. Oxford: Butterworth-Heinemann; 2000. p. 322.

33. Charmaz K. Constructing grounded theory. London., Thousand Oaks, Calif: Sage Publications; 2006. p. $126 \mathrm{e}$.

34. Holloway I, Wheeler S. Qualitative research in nursing. 2nd ed. Oxford: Blackwell Science; 2002. p. 4.

35. Carter SM, Little $M$. Justifying knowledge, justifying method, taking action: epistemologies, methodologies, and methods in qualitative research. Qual Health Res 2007; $17: 1316 \mathrm{e} 28$.

36. Morse JM. Principles of mixed methods and multimethod research design. In: Handbook of mixed methods in social and behavioral research 2003. 189e208.

37. Sackett DL, Rosenberg WM, Gray JA, Haynes RB, Richardson WS. Evidence based medicine: what it is and what it isn't. Br Med J 1996;312:71e2.

38. The Department of Health. Quality agenda. The government's expenditure plans 2000e2001: departmental report 2000. Available from, http://webarchive. nationalarchives.gov.uk; 2000.

39. Kitson AL. Approaches used to implement research findings into nursing practice: report of a study tour to Australia and New Zealand. Int J Nurs Pract 2001;7:392e405.

40. Zaidi Z, Iqbal M, Hashim J, Quadri M. Making evidencebased medicine (EBM) doable in developing countries: a locally-tailored workshop for EBM in a Pakistani. Education for Health 2009;22.

41. Sackett DL. Evidence-based medicine: how to practice and teach EBM. 2nd ed. Edinburgh: Churchill Livingstone; 2000.

42. Herbert RD, Sherrington C, Maher C, Moseley AM. Evidencebased practice e imperfect but necessary. Physiother Theory Pract: An Int J Physiother 2001;17:201e11.

43. Ross EC, Anderson EZ. The evolution of a physical therapy research curriculum: integrating evidence-based practice and clinical decision making. J Phys Ther Educ 2004;18:52e7.

44. Portney LG. Evidence-based practice and clinical decision making: it's not just the research course anymore. $J$ Phys Ther Educ 2004;18:46e51.

45. Fryer G. Teaching critical thinking in osteopathy - integrating craft knowledge and evidence-informed approaches. Int J Osteopath Med 2008;11:56e61.

46. Licciardone JC. Educating osteopaths to be researchers what role should research methods and statistics have in an undergraduate curriculum? Int J Osteopath Med 2008;11: $62 \mathrm{e} 8$.

47. Leach J. Towards an osteopathic understanding of evidence. Int J Osteopath Med 2008;11:3e6.

48. Thomson OP, Petty NJ, Moore AP. Clinical reasoning in osteopathy - More than just principles? Int J Osteopath Med 2011;14:71e6.

49. Green J. Evidence-based medicine or evidence-informed osteopathy? Osteopathy Today 2000. April: 21e22.

50. Rycroft-Malone J, Seers K, Titchen A, Harvey G, Kitson A, McCormack B. What counts as evidence in evidence-based practice? J Adv Nurs 2004;47:81e90. 
51. Henderson R, Rheault W. Appraising and incorporating qualitative research in evidence-based practice. $J$ Phys Ther Educ 2004;18:35e40.

52. Hancock HC, Easen PR. Evidence based practiceean incomplete model of the relationship between theory and professional work. J Eval Clin Pract 2004;10:187e96.

53. Mykhalovskiy E, Weir L. The problem of evidence-based medicine: directions for social science. Soc Sci Med 2004;59:1059e69.

54. Rosenfeld JA. The view of evidence-based medicine from the trenches: liberating or authoritarian? J Eval Clin Pract 2004; 10:153e5.

55. Porta $M$. Is there life after evidence-based medicine? $J$ Eval Clin Pract 2004;10:147e52.

56. Rolfe G. Validity, trustworthiness and rigour: quality and the idea of qualitative research. J Adv Nurs 2006;53: $304 \mathrm{e} 3100$.

57. Sandelowski $M$. The problem of rigor in qualitative research. ANS: Adv Nurs Sci 1986;8:27e37.

58. Sandelowski $M$. Rigor or rigor mortis: the problem of rigor in qualitative research revisited. Adv Nurs Sci 1993;16: 1 e8.

59. Morse JM, Barrett M, Mayan M, Olson K, Spiers J. Verification strategies for establishing reliability and validity in qualitative research. Int J Qual Methods 2002;1.

60. Whittemore R, Chase SK, Mandle CL. Validity in qualitative research. Qual Health Res 2001;11:522e37.

61. Lincoln YS, Guba EG. Naturalistic inquiry. Beverly Hills, Calif, London: Sage; 1985.

62. Denzin N. Interpretive interactionism. Newbury Park: Sage Publications; 1989.

63. Barbour RS. The role of qualitative research in broadening the 'evidence base' for clinical practice. J Eval Clin Pract 2000;6:155e63.

64. Thomas JR, Nelson JK, Silverman SJ. Research methods in physical activity. Human Kinetics Publishers; 2005.

65. Thornquist E. Diagnostics in physiotherapy e processes, patterns and perspectives. Part II. Adv Physiother 2001;3: 151 e62.

66. Edwards I, Richardson B. Clinical reasoning and population health: decision making for an emerging paradigm of health care. Physiotherapy: Theory Pract. 2008;24: $183 e 93$.

67. Borrell-Carrio F, Suchman AL, Epstein RM. The biopsychosocial model 25 Years Later: principles, practice, and scientifi inquiry. Ann Fam Med 2004;2: $576 \mathrm{e} 82$.

68. Jette AM. Toward a common language for Function, disability, and health. Phys Ther 2006;86:726e34.

69. World Health Organisation. International classification of functioning, disability and health. Geneva: World Health Organization; 2001.

70. Öhman A, Åström L, Malmgren-Olsson E-B. Feldenkrais ${ }^{\circledR}$ therapy as group treatment for chronic pain - a qualitative evaluation. J Bodywork Mov Therap 2011;15:153e61.

71. Sacks JL, Nelson JP. A theory of nonphysical suffering and trust in Hospice patients. Qual Health Res 2007;17: $675 e 89$.

72. Petty NJ, Scholes J, Ellis L. Master's level study: learning transitions towards clinical expertise in physiotherapy. Physiotherapy 2011.

73. Resnik L, Hart DL. Using clinical outcomes to identify expert physical therapists. Phys Ther 2003;83: $990 \mathrm{e} 1002$.

74. Resnik L, Jensen GM. Using clinical outcomes to explore the theory of expert practice in physical therapy. Phys Ther 2003;83:1090e106.
75. Jensen GM, Gwyer J, Shepard KF. Expert practice in physical therapy. Phys Ther 2000;80:28e43. discussion $44 \mathrm{e} 52$.

76. Jensen GM, Gwyer JM, Hack LM, Shepard KF. Expertise in physical therapy practice. Boston, Mass, Oxford: Butterworth-Heinemann; 1999b.

77. Jensen GM, Shepard KF, Gwyer J, Hack LM. Attribute dimensions that distinguish master and novice physical therapy clinicians in orthopedic settings. Phys Ther 1992; 72:711e22.

78. Jensen GM, Shepard KF, Hack LM. The novice versus the experienced clinician: insights into the work of the physical therapist. Phys Ther 1990;70:314e23.

79. Edwards I. Clinical reasoning in three different fields of physiotherapy. A qualitative case study approach. Adelaide: University of South Australia; 2001; vols. I and II. Unpublished PhD dissertation.

80. Edwards I, Delany C. Ethical reasoning. In: Higgs J, Jones $M$, Loftus $\mathrm{S}$, Christensen $\mathrm{N}$, editors. Clinical Reasoning in the Health Professions. 3rd ed., vol. xiii. Oxford: Elsevier Butterworth-Heinemann; 2008. p. 504.

81. Edwards I, Jones M, Carr J, Braunack-Mayer A, Jensen GM. Clinical reasoning strategies in physical therapy. Phys Ther 2004;84:312e33.

82. Trede FV. Physiotherapists' approaches to low back pain education. Physiotherapy 2000;86:427e33.

83. Bhandari M, Montori V, Devereaux PJ, Dosanjh S, Sprague S, Guyatt GH. Challenges to the practice of evidence-based medicine during residents' surgical training: a qualitative study using grounded theory. In: Academic medicine 2003; vol. 78. 1183e1190.

84. Clarke KA, Iphofen R. Accepting pain management or seeking pain Cure: an exploration of patients' attitudes to chronic pain. Pain Manag Nurs 2007;8:102e10.

85. Criddle L. Healing from surgery: a phenomenological study. J Nurs Scholar 1993;25:208e13.

86. Richards J, Hubbert AO. Experiences of expert Nurses in caring for patients with postoperative pain. Pain Manag Nurs 2007;8:17e24.

87. Kitty Gahnström-Strandqvist KT, Josephsson S, Borell L. Actions of Competence in Occupational therapy practice: a phenomenological study of practice in narrative form. Scand J Occup Ther 2000;7:15e25.

88. Bjerså K, Forsberg A, Fagevik Olsén M. Perceptions of complementary therapies among Swedish registered professions in surgical care. Complement Ther Clin Pract 2011;17:44e9.

89. Dornan T, Scherpbier A, King N, Boshuizen H. Clinical teachers and problem-based learning: a phenomenological study. Med Educ 2005;39:163e70.

90. Strunin L, Boden LI. Family consequences of chronic back pain. Soc Sci Med 2004;58:1385e93.

91. Winance M. Pain, disability and rehabilitation practices. A phenomenological perspective. Disabil Rehabil 2006;28: 1109 e18.

92. James I, Andershed B, Gustavsson B, Ternestedt B-M. Knowledge constructions in nursing practice: understanding and integrating different forms of knowledge. Qual Health Res 2010;20:1500e18.

93. Thomson DD. An ethnographic study of physiotherapists' perceptions of their interactions with patients on a chronic pain unit. Physiother Theory Pract 2008;24: $408 \mathrm{e} 22$.

94. Brown D, McCormack B. Determining factors that have an impact upon effective evidence-based pain management with older people, following colorectal surgery: an ethnographic study. J Clin Nurs 2006;15:1287e98. 
95. Antrobus S, Kitson A. Nursing leadership: influencing and shaping health policy and nursing practice. J Adv Nurs 1999;29:746e53.

96. Ballinger C, Payne S. Falling from grace or into expert hands? Alternative accounts about falling in older people. Br J Occup Ther 2000;63:573e9.

97. Ballinger $C$, Payne $S$. The construction of the risk of falling among and by older people. Ageing Society 2002;22: $305 e 24$.

98. Talvitie U, Reunanen M. Interaction between physiotherapists and patients in stroke treatment. Physiotherapy 2002;88:77e88.

99. Spalding $\mathrm{N}$. The empowerment of clients through preoperative education. Br J Occup Ther 2000;63:148e54.

100. Powers PA. Discourse analysis of nursing diagnosis. Qual Health Res 2002;12:945e65.

101. Laitinen-Väänänen S, Talvitie U, Luukka MR. Clinical supervision as an interaction between the clinical educator and the student. Physiother Theory Pract 2007; 23:95e103.

102. Lupton D, McLean J. Representing doctors: discourses and images in the Australian press. Soc Sci Med 1998;46:947e 58.

103. Corbin JM, Strauss A. Grounded theory research: procedures, canons, and evaluative criteria. Qual Sociol 1990; 13:3e21.

104. Van Manen M. Researching lived experience. Althouse; 1990.

105. Kvale S. Doing interviews. The Sage qualitative research kit. Thousand Oaks, CA: Sage Publications; 2007.

106. Hammersley M, Atkinson P. Ethnography: principles in practice. Taylor \& Francis; 2007.

107. Starks H, Brown Trinidad S. Choose your method: a comparison of phenomenology, discourse analysis, and grounded theory. Qual Health Res 2007; 17:1372e4.

108. Hutchby I, Wooffitt R. Conversation analysis: principles, practices, and applications. Polity; 1998. 